\title{
PASSIFLORA CAERULEA L. TREATED WITH TRICHODERMA PLANT BIOSTIMULANTS CONSORTIUM. MORPHO-ANATOMICAL CONSIDERATIONS
}

\author{
Anca SÂRBU ${ }^{*}$, Monica Anca PARASCHIV ${ }^{2}$, \\ Florin OANCEA ${ }^{2,5}$, Tatiana Eugenia SESAN ${ }^{1,3,4 *}$ \\ ${ }^{1}$ University of Bucharest, Department of Botany and Microbiology \\ ${ }^{2}$ University of Bucharest, Botanical Garden Dimitrie Brândză \\ ${ }^{3}$ National Research \& Development Institute for Chemistry and Petrochemistry (INCDCP) c \\ (ICECHIM) - Romania \\ ${ }^{4}$ Academy of Agricultural Sciences and Forestry, Bucharest - Romania \\ ${ }^{5}$ University of Agronomical Sciences and Veterinary Medicine, Biotechnology Faculty - Doctoral \\ School, Bucharest - Romania \\ *Corresponding authors. E-mail: anchusa24@yahoo.com; tatianasesan@yahoo.com
}

\begin{abstract}
Plant biostimulants are an emerging category of inputs into technologies for plant cultivation, which activate plant metabolism and nutrient use efficiency. A microbial plant biostimulants consortium was applied on Passiflora caerulea L., a medicinal and nutraceutical plant grown in greenhouse conditions. The treatments were applied during $P$. caerulea vegetation, as a foliar treatment with a Trichoderma consortium suspension of $10^{8} \mathrm{cfu} / \mathrm{ml}$, equiv. to $10^{13}$ spores/ha. The treatment determined significant quantitative changes on morpho-anatomical features, on the leaf lamina (lamina with 10-20\% thicker, palisadic cells with 10-20\% longer, larger stomata and stomatal index increased by $15 \%$ ), on the leaf petiole (the diameter $\sim 30 \%$ larger, conducting bundles, $20 \%$ more developed, the adaxial conducting bundles, $\sim 30 \%$ increase) and on the stem (the diameter with 15-20\% larger, central cylinder with 15$20 \%$ bigger, xylem vessels of more than $50 \mu \mathrm{m}$ diameter, with $20 \%$ more present). These morphoanatomical features demonstrate the plant biostimulants effects of Trichoderma consortium. The results presented here sustain with morpho-anatomical data the accumulation the bioactive compounds, mainly polyphenols and flavonoids with an increased antioxidant activity, which we already reported. Larger stems and leaves of $P$. caerulea, allow accumulation at a higher level of bioactives compounds.
\end{abstract}

Key words: Passiflora caerulea, nutraceutical crop, plant biostimulants Trichoderma consortium, structural effects, stems and leaves.

\section{Introduction}

The present scientific work is referring to Passiflora caerulea L. plants, which have been treated during the vegetation period, with a suspension of Trichoderma-plant biostimulants consortium, consisting of two strains applied together. This multifunctional consortium was demonstrated to stimulate the early stage of plant development and to promote the synthesis and accumulation of biologically active compounds [RĂUŢ \& al. 2014, 2015; ŞESAN \& al. 2018].

The morpho-anatomical researches carried out on the $P$. caerulea plants, treated with Trichoderma, aim to identify the biostimulants effects of the treatment on the leaves and stems development, reported in our previous paper [ŞESAN \& al. 2018, in press], emphasizing on the development of the conducting tissues and the leaf structures, involved in photosynthesis. To the best of our knowledge such approaches haven't been yet performed 
till now and represent the scientific novelty of this work, both at national and international level of plant morpho-anatomical domain.

In this respect, two sets of data were used in this work: (i) the data of the Passiflora caerulea untreated plants, published in 2016 in the scientific approach "Passiflora spp. - new nutraceutical crop in Romania" [SSESAN \& al. 2016; SAVIN \& al. 2016] and considered the control plant and ii) the data of $P$. caerulea plants treated with Trichoderma consortium bioproduct. It has to be mentioned here that both experimental treatments, untreated plants (control) and plants treated with suspension of Trichoderma consortium, have been carried during the 2015 vegetation period and the anatomical investigations have been performed in the laboratory during 2015-2017.

\section{Material and methods}

Biological material consisted in leaves and stems of Passiflora caerulea plants, treated on the early vegetation period, with a foliar suspension of Trichoderma $\left(10^{8} \mu \mathrm{fc} / \mathrm{ml}\right)$, in the watering standard of 200 1/ha [RĂUȚ \& al. 2014, 2015; ŞESAN \& al. 2018].

The Trichoderma consortium contained in two plant biostimulants strains of Trichoderma, both deposited on the National Collection of Agricultural and Industrial Microorganisms (NCAIM), Budapest, Hungary, T. asperellum T36b, NCAIM F 001434 and T. harzianum, Td50b, NCAIM F001412 [RĂUŢ \& al. 2014, 2015]. Preparation of Trichoderma consortium suspensions for the foliar treatments: The two strains of Trichoderma have been cultivated in Petri plates on the solid PDA medium, incubated for 5 days at $28{ }^{\circ} \mathrm{C}$, spores having been collected in sterile distillate water. For each Trichoderma isolates spores having been counted at the value $10^{8} \mathrm{cfu}$. The mixing rate of two isolates for obtaining Trichoderma consortium was 1:1.

The samples for anatomical analyses were collected on 23 of June 2015, from the Hofigal experimental field and preserved in $70 \%$ ethylic alcohol.

For histo-anatomical evaluation, the usual investigation and evaluation methods used in plant anatomy have been applied [ŞERBĂNESCU-JITARIU \& al. 1983; SÂRBU \& al. 2014; ŞESAN \& al. 2016].

The Passiflora leaves and stems have been cross cut (anatomical knife), in the median zone of lamina segments, petiole and stems internodes from the median zone of the stems. Sections have been processed in accordance with the standard stages of the double staining technique [ŞERBĂNESCU-JITARIU \& al. 1983]. Two differential and successive colorants have been used: Iodine green and Carmin Alum. To highlight the starch, IIK has been used. Paradermal sections were prepared, in order to observe the characteristics of the epidermis and the lacunose parenchyma cells, in apical view.

The microscopic analysis of the slides has been performed in normal and polarized lights (crystals study), with an optical microscope, DOCUVAL type. Microphotographs have been carried out, on the same microscope, using a Nikon D90 digital camera.

\section{Results and discussions}

\section{Histo-anatomical evaluation}

Leaves (PLATE I - II, Figures 1-9, Table 1)

Lamina. From the morphological point of view, the Passiflora caerulea lamina is simple, palmat-partite, with 5 unequally lobes (segments), ovat-lanceolate with acute apex, serrate border and penat nervation. The lamina segments are approximately $230-260 \mu \mathrm{m}$ 
width, hypostomatic and develop a dorsi-ventral structure. Tector or secretor trichoms were not observed on the level of the lamina epidermis (Figure 1,2).

Median nervure of the leaf segment (500-550 $\mu \mathrm{m}$ width), has an adaxial part approximately flat and an abaxial one, with a proeminent semi-circular shape (Figure 1).

Epidermis presents proper epidermal cells, of a heterodiametric form (20-30 $\mu \mathrm{m}$ width $\times$ 60-80 $\mu \mathrm{m}$ length), with extern tangential wall thickened ( 3-4 $\mu \mathrm{m}$ thickness) and covered with a cuticle of about 1-3 $\mu$ m thickness (Figure 3,5). At the level of the median nervure the epidermal cells are smaller and approximately isodiametric. Abaxial epidermis presents also stomata cells and stomatal annexes cells (Figure 4, 5).

Stomata $(18 \mu \mathrm{m}$ width $\times 24 \mu \mathrm{m}$ length) are as anomocitic and anisocitic types and are present only at the level of abaxial epidermis (460- stomata $/ 1 \mathrm{~mm}^{2}$ ).

Conducting tissues are organised in conducting bundles of collateral type: 1 - large bundle, disposed in the compact ground parenchyma of the median nervure of the leaf segment and 6-8 small bundles, located in the secondary nervures, at the mesophyll level (Figure 1). In all the conducting bundles, the xylem belt is adaxially oriented.

Mesophyll is differentiated in two zones: palisadic tissue, adaxially located and consisting in 1 - layer of vertically elongated assimilatory cells (90-120 $\mu \mathrm{m}$ length) and lacunose parenchyma, abaxially located and composed of spherical, slightly elongated cells and groups of more elongated cells (Figure 2,4). Gaps of different sizes are present between the cells of the lacunose parenchyma.

Mechanical tissue consists in an angular collenchyma, observed / detected only in the median nervure of the leaf segment, where forms, 3-4 layers adaxially and 1-2 layers abaxially (Figure 1).

Calcium oxalate druses (15-25 $\mu \mathrm{m}$ diameter) are frequent in the structures of the lamina, where are arranged in rows, along the nervures (Figure 6).

Petiole (2.7 mm diameter) has a cylindrical form, is relatively circular in sectional view (Figure 7) and presents an adaxial shallow groove only in its lower zone. The petiole structure is of mono-symmetrical type, with separated conducting bundles.

Epidermis presents small cells, with an isodiametric shape in cross section, and extern tangential wall slightly thickened. Stomata are present, but tector or secretor trichoms missing (Figure 7, 8).

Mechanical tissue is represented by 3-4 subepidermal layers of angular collenchyma, with a discontinuous disposition (Figure 8).

Ground tissue consists of a lax parenchyma, composed of spherical and isodiametric cells, with thin walls (Figure 8).

Conducting tissues are organised in 10-12 conducting bundles of opened collateral type (vascular cambium is present) of different sizes: an adaxial large bundle (550 $\mu \mathrm{m}$ width x $700 \mu \mathrm{m}$ length) and 10-12 smaller bundles (Figure 7, 9). Each of the conducting bundles has amilifera sheath (Figure 9).

Calcium oxalate druses are frequent in the petiole structure, being located both in the phloem parenchyma and ground parenchyma.

Stem (PLATE III, Figures 10-11, Table 2) has a cylindrical shape, irregular-ribbed, of about 2.8-3.3 mm diameter and developed a secondary structure (Figure 10).

Epidermis consists of approximately isodiametric cells in cross section, with slightly thickness walls, covered with a cuticle of 4-5 $\mu \mathrm{m}$ thickness. 
Cortex is differentiated in an extern subepidermal zone, consisting in an angular collenchyma and an intern zone, represented by a lax parenchyma. The angular collenchyma it is more developed (3-4 layers) at the level of ribs. The last layer of the cortex is represented by the amilifera sheath (Figure 11).

Central cylinder is voluminous (2.5-3.0 mm diameter) and has in the center a large pity cavity (1.0-1.2 mm diameter), formed by the disorganization of the central zone of the ground parenchyma. From the activity of the vascular cambium are formed the secondary conducting tissues. These are organized in two rings: an outer ring of secondary phloem and an inner ring of secondary xylem (xylem vessels up to $150 \mu$ m diameter). The primary xylem is located in the inner part of the secondary xylem ring, near the pith cavity and the primary phloem at the periphery of the secondary phloem ring. Packs of sclerenchymatic periphloemic fibres of different sizes, accompany the phloem (Figure 11).

Calcium oxalate druses are abundant in the structure of the stem and are located in different types of cells as epidermal, cortical, phloemic parenchyma cells.

Storage cells (PLATE IV - Figures 12-14).

Possible storage cells for phytochemical products were identified in the lamina of Passiflora caerulea. These are some of the cells of the lacunose parenchyma and the adjacent cells of the stoma (Figure 12, 13, 14).

\section{Comparative aspects}

The comparative analyses of the morpho-anatomical data obtained from the two types of Passiflora caerulea plants, untreated plant (control plants - ŞESAN \& al. 2016) and treated plants with Trichoderma, have allowed the demonstration of the biostimulatory effects of the treatment on the development of the leafs and the stems.

Some quantitative changes were observed in treated plants as compared to untreated plants (Tables 1-3).

Table 1. Analyzed Passiflora caerulea leaf parameters (control and treated with Trichoderma consortium bioproduct)

\begin{tabular}{|c|c|c|}
\hline \multirow{2}{*}{$\begin{array}{c}\text { Leaf } \\
\text { parameters }\end{array}$} & \multicolumn{2}{|c|}{ Measurements / size } \\
\hline & $\begin{array}{c}\text { Control } \\
\text { (ŞESAN et al. 2016) }\end{array}$ & $\begin{array}{c}\text { Treated with Trichoderma } \\
\text { consortium bioproduct }\end{array}$ \\
\hline Median nervure of leaf lobe & $300-350 \mu \mathrm{m}$ thickness & 500-550 $\mu \mathrm{m}$ thickness \\
\hline Leaf lamina & $180-220 \mu \mathrm{m}$ thickness & $230-260 \mu \mathrm{m}$ thickness \\
\hline $\begin{array}{l}\text { Cells in adaxial (superior) } \\
\text { epidermis }\end{array}$ & $\begin{array}{c}20-30 \mu \mathrm{m} \text { width } \times 60-70 \mu \mathrm{m} \\
\text { length }\end{array}$ & $\begin{array}{l}20-30 \mu \mathrm{m} \text { width } \mathrm{x} \\
60-80 \mu \mathrm{m} \text { length }\end{array}$ \\
\hline $\begin{array}{l}\text { Cells in abaxial (inferior) } \\
\text { epidermis }\end{array}$ & $\begin{array}{c}20-40 \mu \mathrm{m} \text { width } \mathrm{x} 40-80 \mu \mathrm{m} \\
\text { length }\end{array}$ & $\begin{array}{c}20-30 \mu \mathrm{m} \text { width } \mathrm{x} \\
40-80 \mu \mathrm{m} \text { length }\end{array}$ \\
\hline Epidermis - extern wall & $3.5 \mu \mathrm{m}$ thickness & $3.4 \mu \mathrm{m}$ thickness \\
\hline Cuticle & $1.2 \mu \mathrm{m}$ & $1.3 \mu \mathrm{m}$ \\
\hline Stomata dimensions & $\begin{array}{l}10 \mu \mathrm{m} \text { width } \mathrm{x} \\
22 \mu \mathrm{m} \text { length }\end{array}$ & $\begin{array}{l}18 \mu \mathrm{m} \text { width } \mathrm{x} \\
24 \mu \mathrm{m} \text { length }\end{array}$ \\
\hline Stomatal index & 390 stomata/mm $\mathrm{mm}^{2}$ & 460 stomata/mm $\mathrm{mm}^{2}$ \\
\hline Palisadic cells dimensions & $\begin{array}{l}\text { 9-10 } \mu \mathrm{m} \text { width } \\
60-80 \mu \mathrm{m} \text { length }\end{array}$ & $\begin{array}{l}15-16 \mu \mathrm{m} \text { width } \\
90-120 \mu \mathrm{m} \text { length }\end{array}$ \\
\hline $\begin{array}{l}\text { Median nervure bundle } \\
\text { dimensions }\end{array}$ & $\begin{array}{l}150-160 \mu \mathrm{m} \text { width } \\
170-180 \mu \mathrm{m} \text { length }\end{array}$ & $\begin{array}{l}200-230 \mu \mathrm{m} \text { width } \\
220-240 \mu \mathrm{m} \text { length }\end{array}$ \\
\hline Petiole diameter & $\begin{array}{c}1.5 \mathrm{~mm} \\
(1.4-1.7 \mathrm{~mm})\end{array}$ & $\begin{array}{c}2.7 \mathrm{~mm} \\
(2.5-3.0 \mathrm{~mm})\end{array}$ \\
\hline Petiole bundle & $8-9$ & $10-12$ \\
\hline
\end{tabular}


ANCA SÂRBU \& al.

\begin{tabular}{|lcc|}
\hline Petiole adaxial bundle & $250 \mu \mathrm{m}$ width $\mathrm{x}$ & $550 \mu \mathrm{m}$ width $\mathrm{x}$ \\
& $300 \mu \mathrm{m}$ length & $700 \mu \mathrm{m}$ length \\
Druses size & $15-20 \mu \mathrm{m}$ diameter & $15-25 \mu \mathrm{m}$ diameter \\
\hline
\end{tabular}

Table 2. Analyzed Passiflora caerulea stem parameters (control and treated with Trichoderma consortium bioproduct)

\begin{tabular}{|lcc|}
\hline \multicolumn{1}{c}{ Stem parameters } & \multicolumn{2}{c|}{ Measurements / size } \\
\cline { 2 - 3 } & $\begin{array}{c}\text { Control } \\
\text { (ŞESAN et al. 2016) }\end{array}$ & $\begin{array}{c}\text { Treated with Trichoderma } \\
\text { consortium bioproduct }\end{array}$ \\
\hline Stem diameter & $2.4-3.0 \mathrm{~mm}$ & $2.8-3.3 \mathrm{~mm}$ \\
Diameter of central cylinder & $2.0-2.2 \mathrm{~mm}$ & $2.5-3.0 \mathrm{~mm}$ \\
Diameter of pity cavity & $0.8-0.9 \mathrm{~mm}$ & $1.0-1.2 \mathrm{~mm}$ \\
Xylem vessels diameter & $10-100 \mu \mathrm{m}$ & $10-150 \mu \mathrm{m}$ \\
Number of xylem vessels & 25 & 34 \\
larger as 50 $\mu \mathrm{m}$ & & $4-5 \mu \mathrm{m}$ thickness \\
Epidermis cells cuticle & $6-7 \mu \mathrm{m}$ thickness & \\
\hline
\end{tabular}

Table 3. Quantitative changes observed in the Passiflora caerulea plants treated with Trichoderma consortium bioproduct as compared to control plants

\begin{tabular}{|c|c|}
\hline The organ & $\begin{array}{l}\begin{array}{l}\text { Quantitative changes of treated plants with Trichoderma consortium } \\
\text { bioproduct }\end{array} \\
\end{array}$ \\
\hline The leaf lamina & $\begin{array}{ll}- & \text { Lamina with } 10-20 \% \text { thicker } \\
\text { - } & \text { Palisadic cells with } 10-20 \% \text { longer } \\
\text { - } & \text { Larger stomata } \\
\text { - } & \text { Stomatal index, } 15 \% \text { increase }\end{array}$ \\
\hline The leaf petiole & $\begin{array}{ll}\text { - } & \text { The diameter with } \sim 30 \% \text { larger } \\
\text { - } & \text { Conducting bundles with } 20 \% \text { more developed } \\
\text { - } & \text { The adaxial conducting bundles with } \sim 30 \% \text { bigger }\end{array}$ \\
\hline The stem & $\begin{array}{l}\text { - } \quad \begin{array}{l}\text { The diameter with } 15-20 \% \text { larger } \\
\text { - }\end{array} \text { Central cylinder } 15-20 \% \text { bigger } \\
\text { - Xylem vessels of more than } 50 \mu \mathrm{m} \text { diameter, } 20 \% \text { more } \\
\text { developed }\end{array}$ \\
\hline
\end{tabular}

The data from tables 1-3, revealed that: (i) the mesophyll is more voluminous, palisadic cells and stomata are larger and the stomatic index is higher; (ii) the petiole has a larger diameter, has more conductive tissue and higher bundles and (iii) the stem is thick, and the conducting tissue from its secondary structure is better represented.

Morpho-anatomical data are important for the autentification of these features in different plants as Passiflora caerulea [VANDERPLANK, 2000; ULMAN \& MacDOUGAL, 2004; ŞESAN \& al. 2016], Panax quinquefolius [LI \& al. 2014], Buttia [SANT'ANA-SANTOS \& al. 2018] a.o. 


\section{Conclusions}

Basic morpho-anatomical features of Passiflora caerulea plants, treated with Trichoderma, have not changed, compared with the untreated plants. In this respect, the following structural aspects are common both types of plants: (i) the leaf lamina has a dorsiventral structure, is hipostomatal and with lack of trichoms; (ii) the leaf petiole has a monosymmetrical structure, with distinct conducting bundles of open collateral type; (iii) the stem has a circular outline, irregular ribbed and a secondary structure, with concentric rings of secondary xylem and phloem; (iv) the mechanical tissue consists of collenchyma in leaf and of collenchyma and sclerenchyma in stem; (v) calcium oxalate crystals of different size are present in both studied organs.

The treatment determined significant quantitative changes on morpho-anatomical features, on the leaf lamina (lamina with 10-20\% thicker, palisadic cells with 10-20\% longer, larger stomata and stomatal index increased by $15 \%$ ), on the leaf petiole (the diameter $\sim 30 \%$ larger, conducting bundles, $20 \%$ more developed, the adaxial conducting bundles, $\sim 30 \%$ increase) and on the stem (the diameter with 15-20\% larger, central cylinder with $15-20 \%$ bigger, xylem vessels of more than $50 \mu \mathrm{m}$ diameter, with $20 \%$ more present). These morphoanatomical features demonstrate the plant biostimulants effects of Trichoderma consortium.

Storage of phytochemical products is related to stomatal annexes cells and lacunose parenchyma cells from the leaf.

Morpho-anatomical data are important for the autentification of these features in different plants as Passiflora caerulea [VANDERPLANK, 2000; ULMAN \& MacDOUGAL, 2004; ŞESAN \& al. 2016], Panax quinquefolius [LI \& al. 2014], Buttia [SANT'ANA-SANTOS \& al. 2018] a.o.

To the best of our knowledge such approaches haven't been yet performed till now and represent the scientific novelty of this work, both at national and international level of plant morpho-anatomical domain.

\section{Notes on contributors}

Tatiana Eugenia ŞESAN - coordinated and monitorized the project 160/2014, performed designed experiments, collected samples from experimental field, gave general interpretation of the data, participate to the writing and finishing the manuscript. Anca SÂRBU and Monica Anca PARASCHIV - performed section of vegetal material and microscopic analysis of the slides, providing anatomical data, their interpretation in connection with the applied treatment in Passiflora crop, all the photos of optical microscopy, drafting and translation of the scientific work. Florin OANCEA contributed and supervised the finalization of the manuscript.

\section{Acknowledgements}

These results are based upon work supported by the Ministry of Research and Innovation, CNDI-UEFISCDI, in the frame of the project number PN-II-PT-PCCA-2013-4-0995 "Multifunctional and innovative products for safe and bioenhanced functional food from newly cultivated plants in Romania" (MAIA, contract 160/2014) and ERA.NET ERA-IB-15-129 "Conversion of phytogenic silica reach food industry by-products into value-added products - CONVERT-Si", contract No. 62/2016, within PNCDI IIII, founded by Romanian Ministry of Research and Innovation, CCCDIUEFISCDI. Many thanks for Georgeta TOMA and Daniela Clara MIHAI for their technical contribution to the processing of the biological material. 


\section{References}

CHINNIAH V. \& THIAGARAJAN V. R. K. 2015. Anatomical investigation on the leaves and stem of Passiflora incarnata (Passifloraceae). International Journal Research Ayurveda Parmacognosy. 6(4) July-August: 537-543; http://dx.doi.org/10.7897/2277-4343.064101; www.ijrap.net.

LI B., SUN M., WANG J. X., REN Y., LIU Y., ZHANG Z. F., LU L. Y., ZHANG J. Z., ZENG R. \& LI L. M. 2014. Authentification of morphological and microscopic features of stem and leaf of Panax quinquefolius L. grown in Ontario, Canada. Advancement in Medicinal Plant Research. 2(2): 34-40.

RĂUŢ I., OANCEA F., ŞESAN T. E., DONI M., ARSENE M. L. \& JECU M. L. 2014. [Biostimulant strain of Trichoderma asperellum and composition based on it to be used in the conservative agricultural systems], Patent RO131177 (A2).

RĂUȚ I., ŞESAN T. E., OANCEA F., DONI M., ARSENIE M. L., JECU M. L. \& CĂLIN M. 2015. [Trichoderma consortium with biostimulating action on cultivated plants], Patent RO131827 (A2).

SANT’ANNA-SANTOS B. F., DOS SANTOS S. A., PEREIRA NUNES E. L., FRANCINO D. M. T. \& CARVALHO JUNIOR W. G. O. 2018. Does leaf anatomy aid in species identification of Buttia (Becc.) Bece. (Arecaceae), https: academic.oup.com/aobpla/advance-article-abstract/doi/10.1093/aobpla/ply046/506 1067.

SAVIN S., TOMA A., CRĂCIUNESCU O., OANCEA A., MĂNOIU S., ŞESAN T. E., SÂRBU A., SMARANDACHE D. \& NEGRU G. 2016. Phytochemical investigations, structural and ultrastructural aspects of the Passiflora caerulea L. plants cultivated in Romania. Analele Şiinţifice ale Universităţii Al. I. Cuza Iaşi. Secţiunea II.a. Biologie Vegetală. 62(1): 138-139.

SÂRBU A. (coord.). 2014. Aspecte de citologie şi histologie vegetală [Aspects of cytology and vegetal histology]. Edit. CERES, Bucureşti, 263 pp.

ŞERBĂNESCU-JITARIU G., ANDREI M., RĂDULESCU-MITROI D. \& PETRIA E. 1983. Practicum de biologie vegetală [Practicum of plant biology]. București: Edit. Ceres, $296 \mathrm{pp}$.

ŞESAN T. E., OANCEA A. O., SAVIN S., TOMA A., ŞTEFAN L. M., GHIUREA M., RĂUȚ I., BIRA F. A., POMOHACI C. M. \& OANCEA F. 2018. Influence of a Trichoderma plant biostimulants consortium on Passiflora caerulea L. morpho-physiological characteristics and accumulation of bioactive compounds. Frontiers in Plant Sciences (in press) (manuscript 412723).

ŞESAN T. E., SÂRBU A., SMARANDACHE D., OANCEA A., OANCEA F., SAVIN S., TOMA A., ŞTEFAN L., NEGRU G., BIRA A. F., VLĂSCEANU G., GHIUREA M., JECU L., VASILESCU G. \& POMOHACI C. M. 2016. Botanical and phytochemical approach on Passiflora spp. - new nutraceutical crop in Romania. J. Plant Develop. 23: 97-126.

ULMAN T. \& MacDOUGAL M. 2004. Passiflora: passionflowers in the world, TIMBER PTESS PortlandCambridge, $430 \mathrm{pp}$.

VANDERPLANK J. 2000. Passion Flowers, $3^{\text {rd }}$ MIT Press Edition Cambridge Massachusetts, 221 pp.

WOSCH L., IMIG D. C., CERVI A. C., MOURA B. B., BUDEL J. M. \& DE MORAES SANTOS C. A. 2015. Comparative study of Passiflora taxa leaves: A morpho-anatomic profile. Revista Brasileira de Farmacognosia. 25: 328-343.

\footnotetext{
How to cite this article:

SÂRBU A., PARASCHIV M. A., OANCEA F. \& ŞESAN T. E. 2018. Passiflora caerulea L. treated with Trichoderma plant biostimulants consortium. Morpho-anatomical considerations. J. Plant Develop. 25 : 3-14. https://doi.org/10.33628/jpd.2018.25.1.3
} 


\section{PLATE I}

\section{Passiflora caerulea - LAMINA}

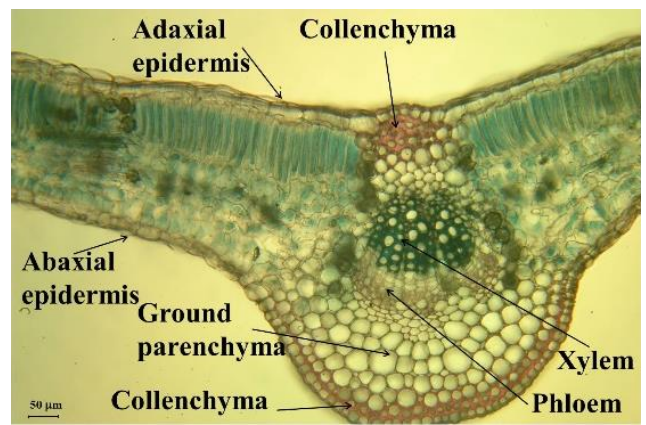

Figure 1

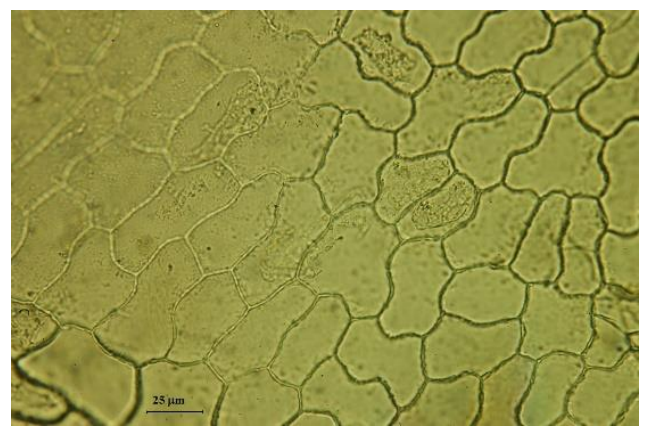

Figure 3

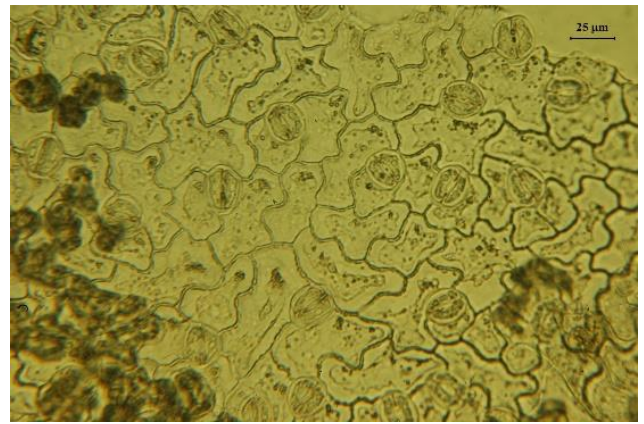

Figure 5

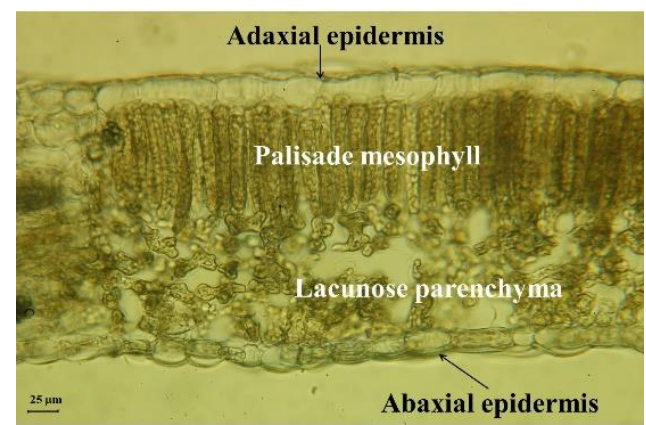

Figure 2

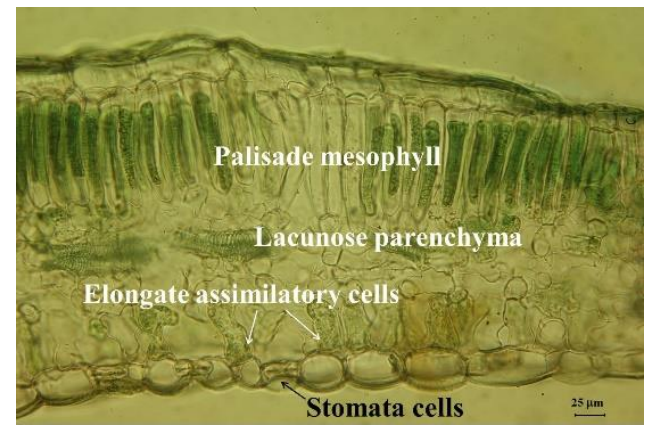

Figure 4

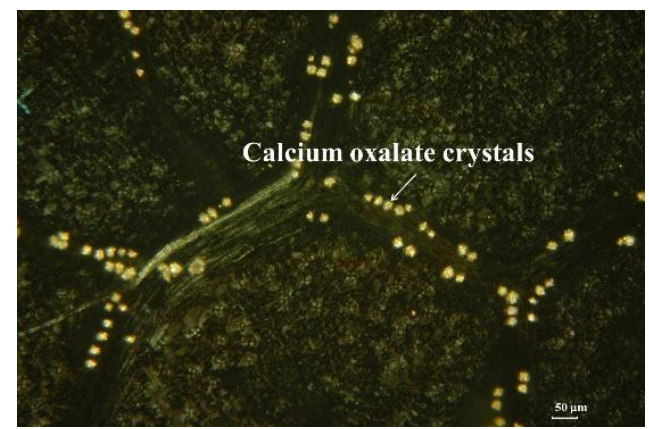

Figure 6 
ANCA SÂRBU \& al.

\section{PLATE II}

Passiflora caerulea - PETIOLE

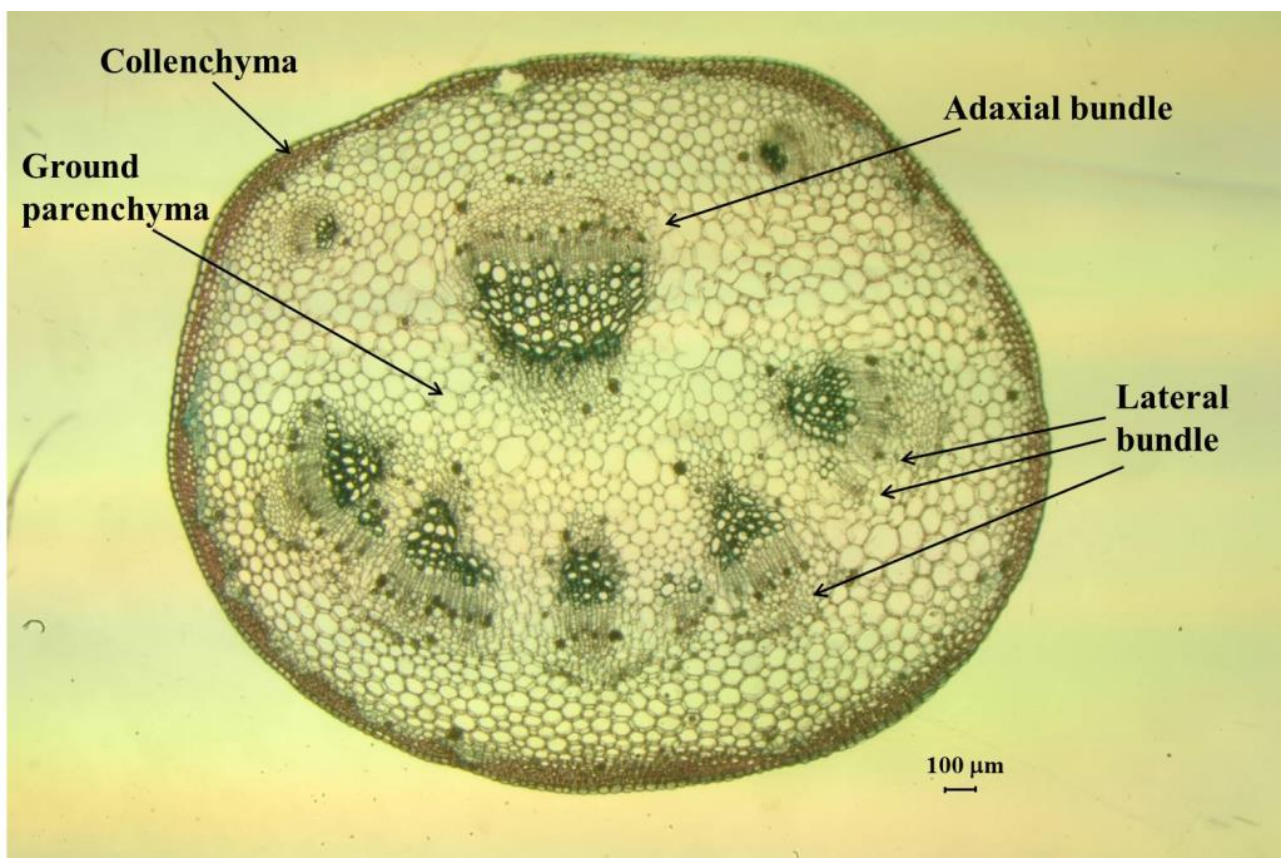

Figure 7

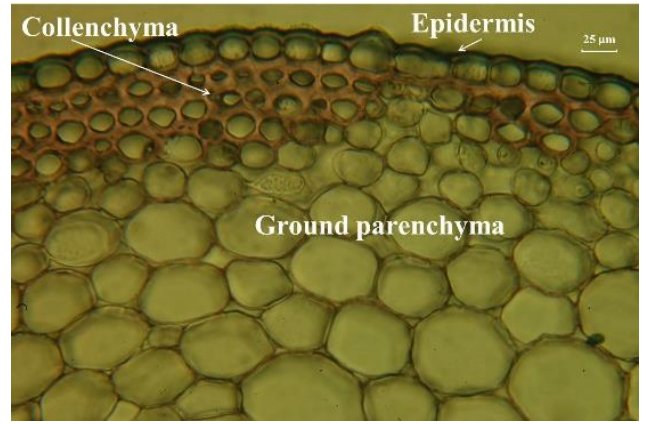

Figure 8

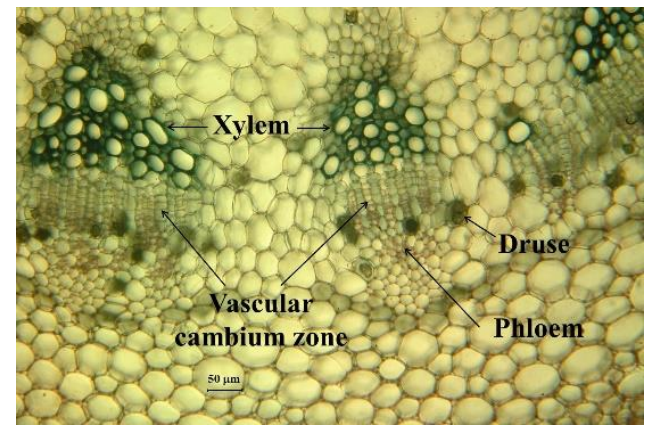

Figure 9 


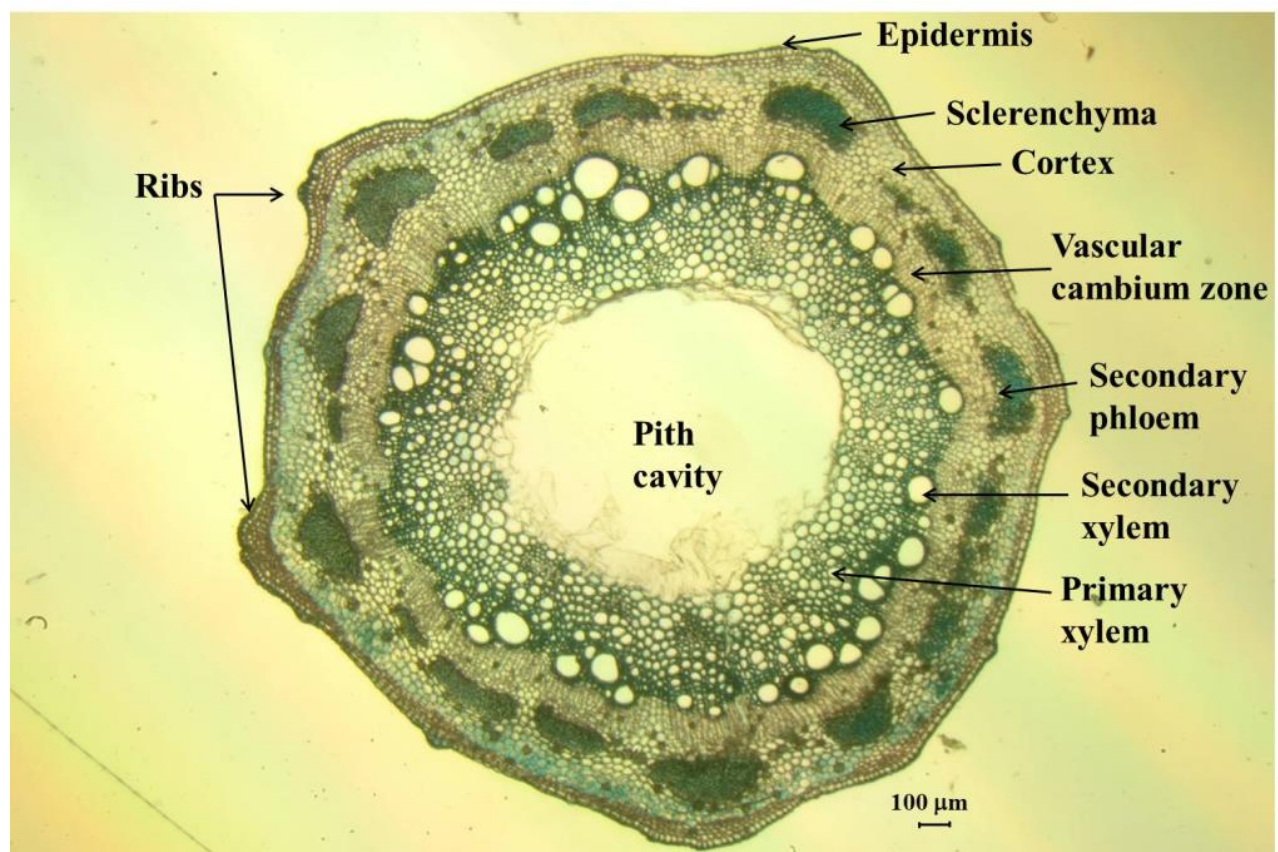

Figure 10

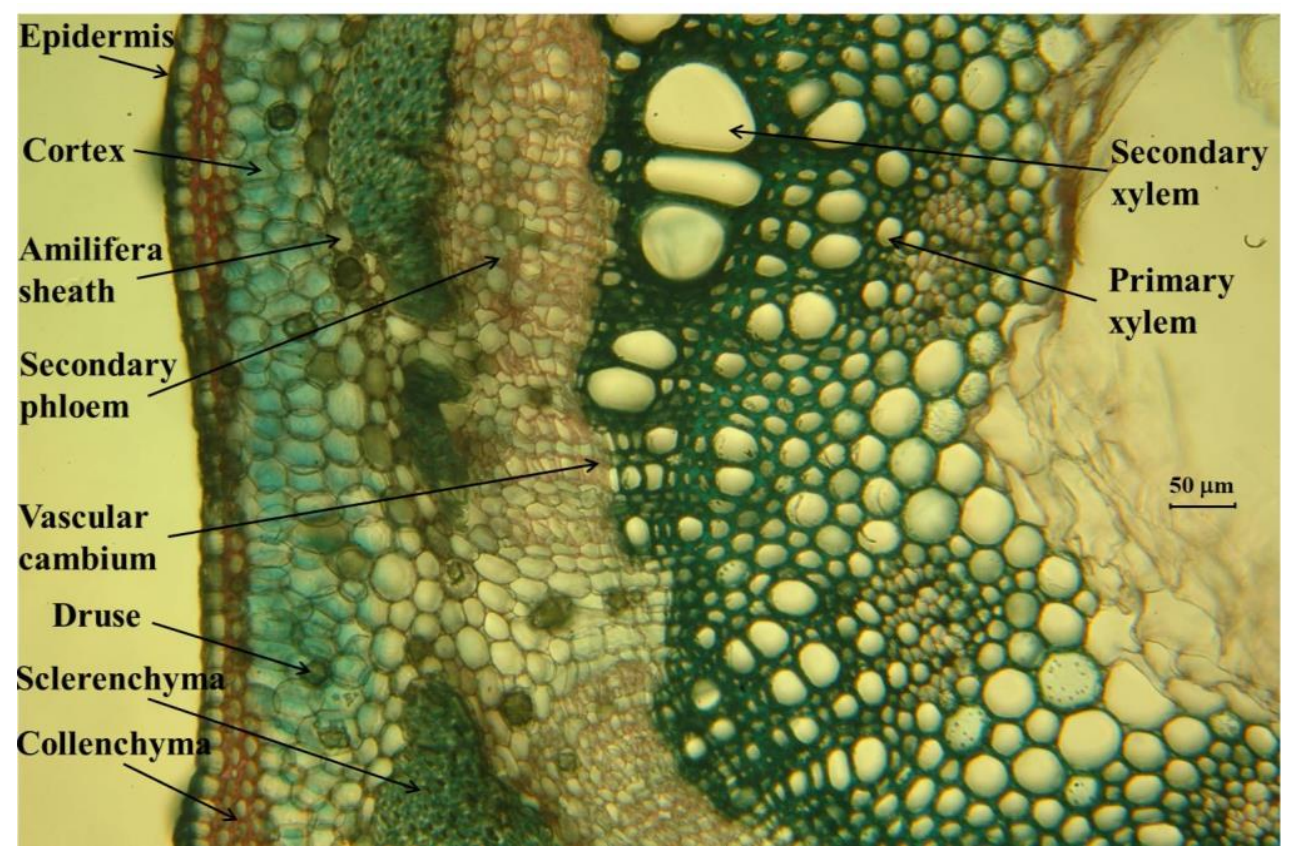

Figure 11

12 
ANCA SÂRBU \& al.

\section{PLATE IV}

\section{Passiflora caerulea - STORAGE CELLS}

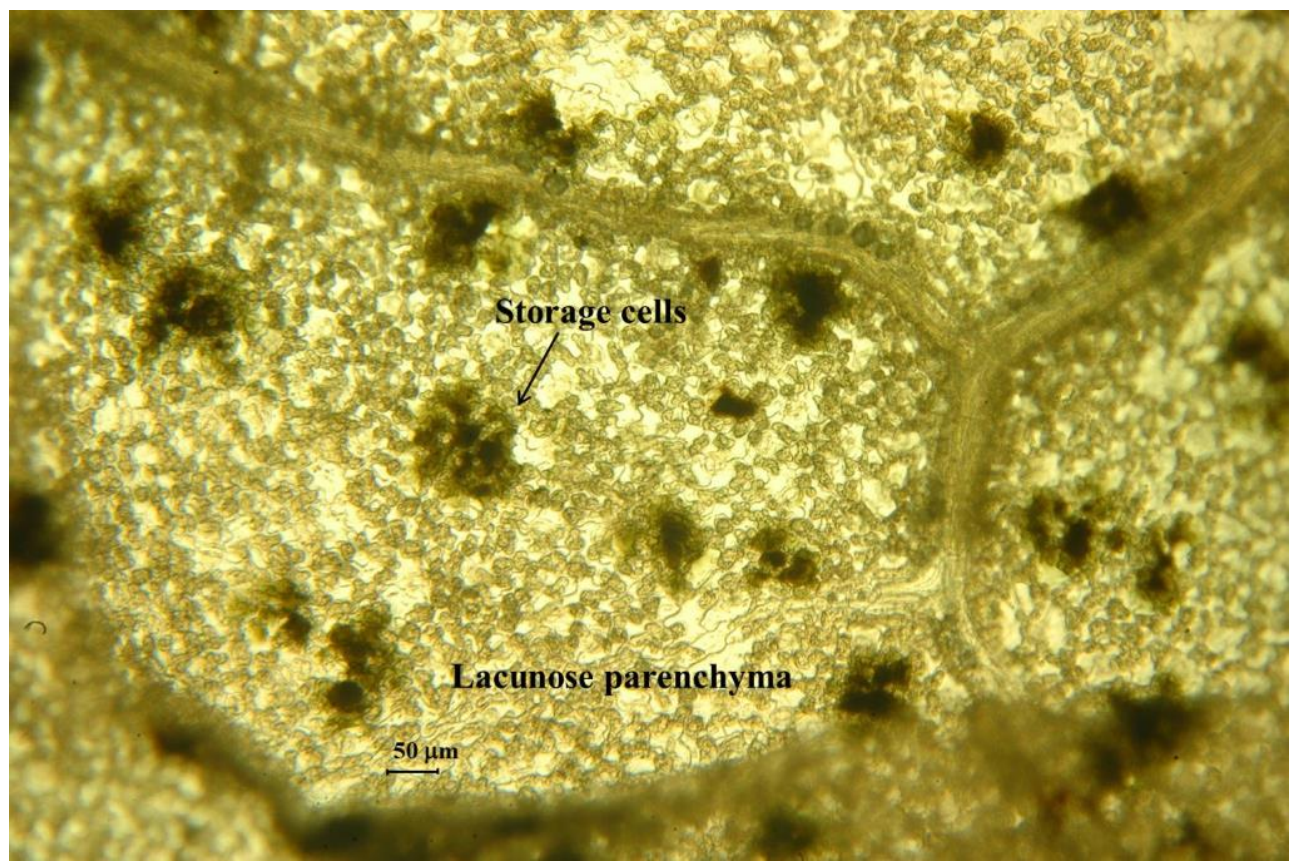

Figure 12

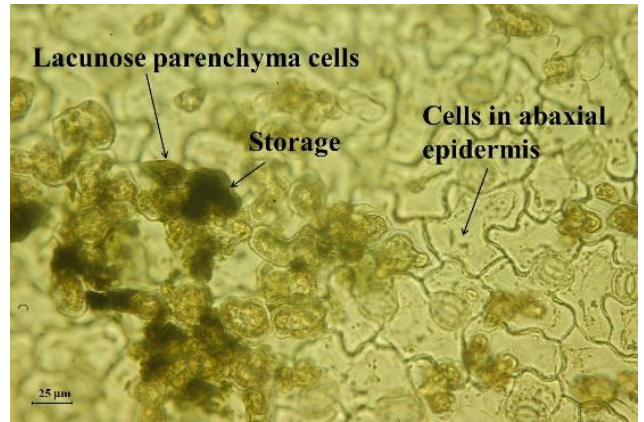

Figure 13

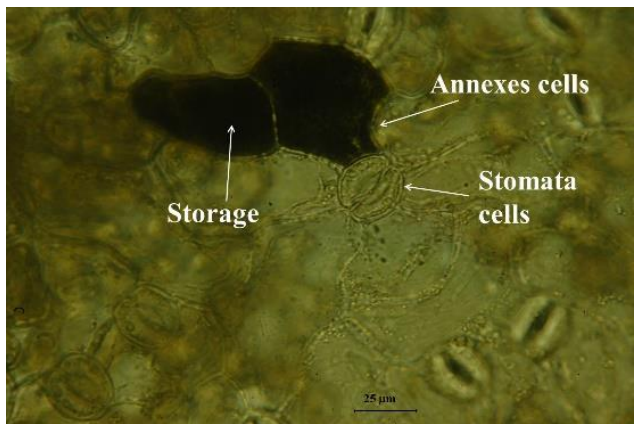

Figure 14 


\section{Explanation of plates and figures}

PLATE I (photo: Anca Sârbu) - Passiflora caerulea - LAMINA

- Cross section through median zone of the leaf segment, with evidence of the median nervure, colorants Iodine green and Carmin Alum (Figure 1)

- Cross section through the median zone of leaf segment, with evidence of epidermis and mesophyll, colorants Iodine green and Carmin Alum (Figure 2)

- Adaxial epidermis (superior) in apical view (Figure 3)

- Cross section through the median zone of leaf segment with evidence of epidermis and assimilatory cells, colorants Iodine green and Carmin Alum (Figure 4)

- Abaxial epidermis (inferior) in apical view (Figure 5)

- Paradermal section through the leaf segment, with evidence of lacunose parenchyma, abaxial epidermis and calcium oxalate crystals in apical view, using polarized lights (Figure 6).

PLATE II (photo: Anca Sârbu) - Passiflora caerulea - PETIOLE

- Cross section through the petiole, colorants Iodine green and Carmin Alum (Figure 7)

- Cross section through the petiole, with evidence of epidermis, collenchyma and ground parenchyma, colorants Iodine green and Carmin Alum (Figure 8)

- Cross section through the petiole, with evidence of the lateral bundles, colorants Iodine green and Carmin Alum (Figure 9)

PLATE III (photo: Anca Sârbu) - Passiflora caerulea - STEM

- Cross section through the median zone of the stem, colorants Iodine green and Carmin Alum (Figure 10)

- Cross section through the median zone of the stem, with evidence of epidermis, cortex and of central cylinder elements, colorants Iodine green and Carmin Alum and IIK (Figure 11)

\section{PLATE IV (photo: Anca Sârbu) - Passiflora caerulea - STORAGE CELLS}

- Paradermal section through the leaf segment, with evidence of lacunose parenchyma and storage of phytochemicals products (Figure 12)

- Paradermal section through the leaf segment, with evidence of phytochemicals products accumulation in the cells (Figure 13)

- Paradermal section through the leaf segment, with evidence of the abaxial epidermis, the stomata cells and the accumulation of phytochemicals products in the adjacent cells (Figure 14) 